\title{
ФОРМАЦІЙНА ТЕОРІЯ: ДЕРЖАВНІ ТА ПРИВАТНІ ФОРМАЦЇ̈
}

\author{
М.М. Брюховецький
}

\begin{abstract}
Анотація. У своєму дослідженні ми виходимо з того, що сучасна соціальна філософія часто звертається до методологічного потенціалу формаційної теорії. Певні модифікації марксистського підходу дозволяють цілком продуктивно використовувати його ідеї для аналізу сучасного суспільства. Проте очевидно, що формаційна теорія має бути очищена від її ідеологічних смислів та догматичних форм. В науковому середовищі сформувалася усталена традиція зовнішньої критики формаційного підходу з позицій інших підходів, насамперед цивілізаційного. Також має місце і внутрішня критика формаційної концепції, спрямована не на її заперечення, а, скоріше, на її вдосконалення. Важливими аспектами такої критики є: проблеми кількості формацій та їх назв, проблема статусу соціалістичної та комуністичної формацій, проблема зміни формацій тощо. Наша мета полягає у тому, щоб представити підхід до розуміння формаційної теорії, здатний принаймні частково подолати деякі з перелічених проблем, окреслених внутрішньою критикою. Таким чином, ми пропонуємо такий погляд на формаційну теорію, при якому всі антагоністичні формації - рабовласництво, феодалізм та капіталізм - мають державну і приватну форму існування. В умовах свого державного різновиду в якості основного власника та експлуататора виступає держава в особі державного апарату. Уявлення про державне рабовласництво та феодалізм дозволяе окреслити в рамках цих формацій азійський спосіб виробництва як окремий уклад, що не піддається класифікації. Державна форма існування феодалізму дозволяе повернути з «окремішнього» шляху Київську Русь та Російську імперію на дорогу загальнолюдського історичного процесу. Державний капіталізм дає змогу переосмислити сторінки так званої соціалістичної історії багатьох країн світу та врешті розгадати феномен сучасного Китаю.
\end{abstract}

Ключові слова: формаційна теорія, державна формація, державний феодалізм, державний капіталізм, державна форма рабовласництва.

\section{FORMATION THEORY: STATE AND PRIVATE FORMATIONS}

\begin{abstract}
In our study, we proceed from the fact that modern social philosophy often refers to the methodological potential of the social formation theory. Certain modifications of the Marxist approach make it possible to use its ideas quite productively for the analysis of modern society. However, it is
\end{abstract}


obvious the formation theory must be cleansed of its ideological meanings and dogmatic forms. In the scientific environment, there is an established tradition of external criticism of the formational approach from the standpoint of others, especially the civilizational one. There is also an internal criticism (critical remarks) of the formation concept, and it aims not at its denial but rather at its improvement. The essential aspects of the internal criticism are the following: the problem of the number of formations and their names, the problem of the status of socialist and communist formations, the issue of formational changing, etc. Our goal is to present such an approach to the understanding of formation theory that is able, at least partially, to overcome some of the enumerated problems, outlined by internal criticism. Thus, we propose a view of formation theory in which all antagonistic formations - slavery, feudalism, and capitalism - have state and private forms. In the state form of the mentioned formations, the state acts as the chief owner and exploiter, represented by the state apparatus. The notion of state slavery and state feudalism allows us to outline within these formations the Asian mode of production as a separate system that cannot be classified. The state form of feudalism allows returning of Kievan Rus' and the Russian Empire from a «separate» way to the path of the universal historical process. State capitalism makes it possible to reconsider the pages of the so-called socialist history of many countries of the world and finally to unravel the phenomenon of modern China.

Keywords: formation theory, state formation, state feudalism, state capitalism, state form of slavery.

Формаційна теорія, незважаючи на негативні ідеологічні асоціації, наразі достатньо широко застосовується як методологія осмислення глобального історичного процесу. Окрім альтернативи цивілізаційній теорії, вона складає собою частину більш загального лінійностадіального підходу до історії і цілком концептуально та системно дозволяє представити розвиток людського суспільства.

Формаційну теорію (або принаймні дискурсивне поле, утворене їі категоріями) активно застосовують сучасні європейські та американські філософи Майкл Гардт та Антоніо Негрі [15], Юрген Габермас [18], Том Рокмор [20], філософ та соціолог Ральф Дарендорф [4], соціологи та історики Перрі Андресон [1] та Імануїл Валлерстайн [3]. На позначення багатьох суспільних явищ термінологію формаційної теорії використовують теоретики інформаційного суспільства Деніел Белл [2], Мануель Кастельс [17], Владислав Іноземцев [8]. Тобто, сучасна філософія та соціальна наука часто звертаються до методологічного потенціалу формаційної теорії. Звісно, вказаний потенціал можна розглядати в якості наукового тільки за умов залишення поза дужками ідеологічних смислів формаційної теорії, уникаючи її догматичних форм та, тим більше, не ставлячись до цієї теорії як до святого непорушного храму.

Крім того, як цього і вимагає справжня наукова теорія, формаційна концепція зазнає постійної критики в науковому середовищі як з боку її послідовників, так і з боку прихильників альтернативних 
підходів, наприклад цивілізаційного. Звісно, що критика не вказує на неспроможність теорії взагалі, а якраз і є підтвердженням її відкритості та науковості.

Так, в науковому середовищі сформувалася усталена традиція критики формаційного підходу з позицій інших підходів, насамперед цивілізаційного. Подібний напрямок критики можна умовно назвати зовнішнім. На противагу цьому напрямку, критику формаційної концепції з позицій діалектико-матеріалістичного методологічного підходу можна назвати внутрішньою. Важливими аспектами такої критики є: проблеми кількості формацій та їх назв («первісна - рабовласницька - феодальна - капіталістична» або «первісна - азійська - антична - феодальна - капіталістична»?), проблема статусу соціалістичної формації (які їі ознаки, природа та місце серед інших?), проблема настання комуністичної формації (чому вона ще не настала та коли їі очікувати?), проблема змін формацій (яким чином одна змінює іншу?) тощо.

3 огляду на зазначене, вбачаємо наразі одним із важливих завдань ознайомлення з таким поглядом на формаційну теорію, в межах якого можна спробувати принаймні частково зняти чи подолати деякі 3 перелічених проблем, окреслених внутрішньою критикою.

\section{I. Проблеми формаційної теорії}

Спробуємо конкретизувати деякі з проблем, що постають з внутрішньої критики формаційної концепції.

1. Проблема існування азійського способу виробництва (східного способу виробництва).

Суть проблеми: невідповідність східного економічного укладу відомим європейським аналогам - античному (або рабовласницькому) та феодальному. Ознаки невідповідності: відсутність приватної власності на землю в східних суспільствах, відсутність класів, подібних західним аналогам, абсолютна влада державного апарату.

Існувати вказана проблема почала з легкої подачі самого творця теорії - К. Маркса та широко цитувалася прихильниками за відомою передмовою «До критики політичної економії (хоча, насправді, перша згадка відноситься до більш раннього листування К. Маркса та Ф. Енгельса) про «азійський, античний, феодальний та сучасний, буржуазний способи виробництва». Характерно, що в пізніх роботах, К. Маркс відмовляється від терміну «азійський спосіб виробництва».

До найбільш фундаментальних «розробників» проблеми належить Карл Віттфогель - відомий німецько-американський соціолог та сіно- 
лог. 3 позицій діалектико-матеріалістичного методу в цілому Віттфогель досліджував історію Китаю і на основі особливостей його економічної та соціальної сфери запропонував так звану гідравлічну (або іригаційну) теорію держави на Сході, а також концепцію Азійського способу виробництва (АСB). Вказані погляди найбільш детально викладені в роботі «Східний деспотизм. Порівняльне дослідження тотальної влади» [21]. Сутність його вчення полягає в тому, що природні особливості розвитку давньокитайського регіону вимагали застосування іригаційного способу землеробства, яке можна було організувати в той час лише масштабними колективними роботами, що, в свою чергу, вимагало потужного та чисельного державного апарату з авторитарними методами управління. Вказані процеси впливали на формування соціальної структури суспільства та на подальші особливості його економіки.

Критика традиційної формаційної концепції у напрямку існування окремого від традиційної п'ятичленки (творець якої - В. Струве) азійського способу виробництва велася великою кількістю дослідників. Так, в якості прикладів можна навести французьких істориків Моріса Годелье та Жана Сюре-Каналя, які переконували, що АСВ - це насправді перехідна стадія до рабовласницького суспільства [5, с. 23].

Сучасний російський філософ-марксист Юрій Семенов обгрунтовує існування політарної формації (від грецького політія - держава), яка суттєво відрізнялася від звичних уявлень про рабовласництво [14, с. 226]. Ференц Тьокеі - угорський філософ, тлумачить АСВ як докласову стадію; Елізабет Вельскопф - німецький історик, вбачає в АСВ особливу антагоністичну формацію [5, с. 23].

\section{2. Проблема феодалізму в Київській Русі і Російській ім- перії (та Східних деспотіях).}

Суть проблеми: Київська Русь та Російська імперія не можуть бути вписані в рамки формаційної теорії у зв'язку з відсутністю рабовласництва та феодалізму в традиційному (західноєвропейському) розумінні цього поняття. Ознаки невідповідності: відсутність звичного феодального землеволодіння на цих територіях, відсутність феодальної ренти в часи Київської Русі, гіпертрофована роль авторитарної влади в суспільно-економічній сфері, залежність дворянства від держави, порівняно велике значення міжнародної торгівлі [13, с. 43].

Заперечували існування феодалізму на Русі та в Російській імперії ще дореволюційні історики - М.А. Дьяконов, В.Й. Ключевський, М.П. Павлов-Сильванський. Так, з огляду на особливості землеволо- 
діння регіону, вони скептично ставилися до терміну «руський (російський) феодалізм» та пропонували свої варіанти тлумачення суспільного ладу на Русі і в Російській імперії [13, с. 33-34].

K. Віттфогель характеризував Російську імперію як неєвропейську країну з рисами азійського соціально-економічного розвитку. Кобрін В.Б. вказує на відсутність великого вотчинного землеволодіння в Київській Русі, що віддаляло її від західноєвропейського феодалізму [13, с. 38-39]. На відсутність аллодіальної власності на землю, характерної для традиційного феодалізму в звичному західноевпропейському вигляді вказує американський історик Річард Пайпс [11, с. 227]. Німецькі історики У. Хальбах і Х. Рюс заперечують існування феодалізму в регіоні з огляду на особливості місцевого землеволодіння [13, с. 45]. За великим рахунком, лише радянська офіційна історіографія вказувала на дієвість формаційної теорії щодо Київської Русі та Російської імперії.

\section{3. Проблема соціалізму в СРСР та в сучасному Китаї.}

Суть проблеми у вимірі СРСР: в політекономічній думці існує цілий напрям, згідно якого приблизно з 1930-х років в СРСР, з огляду на його економічний розвиток, не можна говорити про існування соціалістичного ладу.

Ознаки невідповідності: одержавлення засобів виробництва, бюрократизація державного апарату - розгалужена система чиновників, директорів та адміністрації підприємств, система окремих привілеїв для партійної номенклатури, зростання соціальної нерівності, системна інтеграція в світову капіталістичну економіку.

Суть проблеми у вимірі Китаю: назва офіційної ідеології Комуністичної партії Китаю, занесена до відповідного статуту партії, звучить як «Соціалізм $з$ китайською специфікою». Незважаючи на це, офіційними членами партії, в тому числі й такими, що перебувають на відповідальних керівних посадах, є середні та великі підприємці, тобто представники буржуазії (що намагаються обгрунтувати концепцією «потрійного представництва»).

Ознаки невідповідності: приватна власність на землю та по суті деколективізація (з 1982 р.), ринок як саморегулятор цін (з часу тих самих реформ), наявність компаній з повністю приватним капіталом BYD, Geely, Chery, Huawei, надмірно висока різниця між фактичним доходом чиновника та робітника.

Тобто, колишній СРСР та сучасний Китай, як ймовірно, і всі інші країни з так званими соціалістичними режимами, в ході аналізу 
демонструють зовсім іншу систему економічного укладу, відмінну від офіційно-ідеологічної назви «соціалізм».

Подібної думки дотримується велика частина незаідеологізованих послідовників діалектико-матеріалістичного методу, починаючи ще 3 Г. Плеханова та пізніше Л. Троцького. Так, Г. Плеханов в «Соціалізмі і політичній боротьбі» застерігав від небезпеки утворення своєрідної «соціалістичної касти», яка буде фактично володіти всім національним виробництвом та яку буде обслуговувати робітничий клас $[12$, с. 105-106]. Л. Троцький в «Зрадженій революції називає СРСР часів Й. Сталіна «деформованою робітничою державою», британський марксист Тоні Кліфф в роботі «Державний капіталізм в Росії» вказує, що великі державні чиновники по суті виступають експлуататорами робітників в СРСР [9]. Подібної думки дотримується англійський історик Джеймс Сиріл. Відомий американський історик та соціолог Імануїл Валлерстайн в «Історичному капіталізмі» вказує, що буржуазія вбралася в соціалістичний одяг i, намагаючись створити альтернативну капіталізму історичну систему, здійснює експлуатацію світової робочої сили до вигоди меншості [3, с. 138].

Таким чином, історія демонструє велику кількість прикладів суспільств, які не лише не вписуються в рамки тих чи інших формацій, а навіть певною мірою суперечать традиційній формаційній концепції. При цьому, такі приклади невідповідності існують щодо кожної антагоністичної формації: відсутність «класичного» рабовласництва на Стародавньому Сході, а також у слов'янських народів; «особливий» тип феодалізму Київської Русі, Російської імперії, а також Східних деспотичних держав; соціалістичний капіталізм (або навпаки - капіталістичний соціалізм) в колишньому СРСР та сучасній КНР.

\section{II. Державний капіталізм та його ознаки}

Варіантом розв'язання останньої проблеми є теорія державного капіталізму. Це теорія досить авторитетних дослідників (ï підтримують британський соціолог Девід Лейн [10], філософ Алекс Калінікос [16], вже згадувані Імануїл Валлерстайн та Джеймс Сиріл), відповідно до якої в окремних державах роль класу капіталістів може взяти на себе безпосередньо держава, здійснюючи капіталістичну експлуатацію населення. СРСР з початку 1930-х років, Китай, деякі інші країни «соціалістичного табору» слугують ілюстрацією подібного явища. Показово, що вказана теорія загалом не суперечить формаційній концепції, а радше доповнює її своєрідним різновидом існування капіталістичної 
формації.

Можна назвати такі ознаки державного капіталізму:

- держава як власник засобів виробництва та предметів праці;

- гіпертрофований державний апарат з чисельною бюрократією, партійною номенклатурою тощо;

- концентрація та монополізація виробництва в руках держави;

- значний розрив в доходах між чиновниками та робітниками фактичний або у вигляді системи привілеїв.

Дійсно, якщо під цим кутом зору розглянути, наприклад, СРСР, то долається багато суперечностей, які не могли бути пояснені «перехідним характером радянської економіки до комунізму». Так, Тоні Кліфф, характеризуючи суспільно-економічний устрій СРСР, зазначав про можливість капіталізму з одним капіталістом - державою, за якого партійна номенклатура привласнює додаткову вартість і це все разом по суті являє собою форму бюрократичного державного капіталізму [9].

Сучасні американські економісти Стефан Резнік та Річард Вольф в роботі 2002 року «Класова теорія та історія: капіталізм і комунізм в СРСР» [19] вказують, що суспільства радянського типу насправді відносилися до капіталістичного ладу, хоча і з одержавленим господарством (як це було в нацистській Німеччині). Панівний клас капіталістів (держава) вилучав додаткову вартість, експлуатував робітничий клас та перерозподіляв прибуток на свою користь [10, с. 54]. Цієї ж думки тяжіють американські економісти і соціологи Петер Біннс та Кріс Харман, які в співавторстві з Тоні Кліфом досліджують еволюцію СРСР від робітничої держави до державного капіталізму на підставі такої ознаки як накопичення капіталу в руках правлячої верхівки (робота «Росія: від робітничої держави до державного капіталізму») [10, с. 54]. Тобто, теорія державного капіталізму в цілому в рамках формаційної концепції може пояснити деякі особливості суспільно-економічного устрою так званих «соціалістичних» держав.

\section{III. Держава в ролі панівного класу в рабовласництві та феодалізмі}

Якщо зараз нікого не здивувати таким поняттям як «державний капіталізм», то термін «державний феодалізм» мало відомий науковому співтовариству та сприймається досить неоднозначно, а термін «державне рабовласництво» може навіть викликати подив. Проте, якщо екстраполювати ознаки державного капіталізму на інші антагоністи- 
чні формації, такі як рабовласництво та феодалізм, то отриманими висновками можна спробувати зняти деякі вищезгадані проблеми теорії формації.

Для початку, розглянемо, що спільного в різних антагоністичних формаціях та чим вони відрізняються одна від одної. Головна спільна риса, яку, в принципі, можна назвати атрибутом антагоністичної формації - це експлуатація та, відповідно, наявність двох антагоністичних класів. Головна відмінність між антагоністичними формаціями спосіб експлуатації: рабовласницька, феодальна, капіталістична. Відмінність способу експлуатації одного від іншого, в свою чергу, породжується такими ознаками як власність на предмети праці, власність на засоби праці та форму експлуатації. Такі відмінності можна систематизувати в короткій таблиці.

Табл. 1. Соціально-економічні характеристики рабовласництва, феодалізму та капіталізму

\begin{tabular}{|l|l|l|l|}
\hline & $\begin{array}{l}\text { Власність на } \\
\text { предмети праці }\end{array}$ & $\begin{array}{l}\text { Власність на } \\
\text { засоби праці }\end{array}$ & $\begin{array}{l}\text { Форма експлуа- } \\
\text { тації }\end{array}$ \\
\hline \hline Рабовласництво & панівний клас & панівний клас & $\begin{array}{l}\text { прямий позаеко- } \\
\text { номічний примус }\end{array}$ \\
\hline Феодалізм & панівний клас & підлеглий клас & $\begin{array}{l}\text { прямий позаеко- } \\
\text { номічний примус }\end{array}$ \\
\hline Капіталізм & панівний клас & панівний клас & $\begin{array}{l}\text { непрямий еконо- } \\
\text { мічний примус }\end{array}$ \\
\hline
\end{tabular}

Як вже було згадано вище, особливість державного капіталізму полягає в тому, що панівний клас уособлюється державою. Таким чином, держава здійснює експлуатацію за умов володіння засобами виробництва та предметами праці.

Проте подібна ситуація - експлуатація за умов власності на предмети праці - цілком можлива і за умов рабовласництва та феодалізму. На підтвердження існування такої власності в Російській імперії на предмети праці (основний з яких, як відомо, за феодалізму - це земля) можна навести позицію німецького історика Уве Хальбаха, який вказує на нетипову особливість давньоруської знаті, яка не була зацікавлена в земельних володіннях, але натомість тяжіла до служби при князі. Схожої думки дотримується інший німецький історик Хартмут Рюсс, який вказує на залежність давньорускої знаті від монарха та відсутність власних політичних орієнтирів та станових інтересів. На відсутність традиційних феодальних садиб в Стародавній Русі вказує російський історик Василь Ключевський, який на цій підставі взагалі 
відмовляв Русі в феодалізмі. Головної ознаки феодалізму в Київській Русі - служби з землі - не знаходив і російський історик Михайло Дьяконов. М.М. Тихомиров виводить початок формування феодалізму в регіоні з XII століття, після появи «милостників»- осіб, що отримали від держави землю в «умовне утримання» (див.: [13, с. 34-37]).

На підтвердження власності держави на землю як основний предмет праці за феодалізму в Російській імперії можна навести фундаментальну роботу американського історика Річарда Пайпса «Росія при старому режимі» [11]. Так, наприклад, він наводить факти, відповідно до яких після опричнини Івана Грозного втрачає своє значення приватна власність на землю та родинну вотчину витісняє ленний маєток. Він наголошує, що відразу після своєї появи централізована монархія на Русі ліквідує аллодіальну власність на землю (більш характерну для західноєвропейського феодалізму) та замінює її умовним землеволодінням, яке залежить від державної служби. Відтак, встановлюється «монополія корони» практично на всю землю, а також на промисловість і торгівлю. На відміну від Західної Європи, в Російській імперії «монархія ніколи не давала своєму служилому класу пускати коріння в селі [...]. Державна влада в Росії була вибудувана на руїнах приватної власності, шляхом безжалісного знищення наділів та інших вотчин» [11, с. 227].

Володіння землею як головним предметом праці та феодальна експлуатація населення зі сторони держави на теренах Стародавнього Сходу обгрунтовує Сергій Ковальов - радянський історик античності, коли розглядає державу як колективного власника засобів виробництва: організовану в державний апарат групу експлуататорів за відсутності розчленування власності $[6$, с. 80$]$; подібну думку висловлює Жан Шено - французький сінолог та етнограф, згідно якого державна влада «одночасно експлуатує громади та керує ними» [7, с. 48].

За даними, які наводить російський історик та єгиптолог О.Д. Берлев в роботі «Трудове населення Єгипту в епоху середнього царства», велика частина трудящого населення були рабами не свого господаря, а царя. Масове використання рабства в царських господарствах спостерігалося в Стародавній Персіі. На позначення державних рабів в Стародавному Китаї існувало два спеціальних терміни «гун» і «ту», на відміну від «ну» і «бей», які означали приватних рабів.

Таким чином, існує велика кількість історичних досліджень, які прямо чи опосередковано підтверджують існування особливих державно-рабовласницьких чи державно-феодальних відносин в Східних деспотіях, Київській Русі, Російській імперії. В таких дослідженнях існу- 
ють підтвердження належності панівного класу до «служилих людей», тобто чиновництва чи державного апарату, власності держави на землю як основний предмет праці, іноді - на засоби виробництва як умову експлуатації, а також, власне, підтвердження самої експлуатації населення зі сторони державного апарату.

\section{IV. Державна форма рабовласництва, феодалізму та капіталізму}

Таким чином, в кожній з антагоністичних формацій (рабовласницькій, феодальній, капіталістичній) можна спробувати виділити приватну і державну форму їі існування. Так, суб'єктом неекономічної експлуатації в приватній формі рабовласництва та феодалізму виступають приватні власники - представники панівного класу рабовласників чи феодалів. Натомість суб'єктом неекономічної експлуатації в державній формі рабовласництва та феодалізму виступають службові особи державного апарату. Так само розрізняється приватна і державна форма цих формацій за критеріями власності на предмети праці на відміну від приватної власності традиційного рабовласництва і феодалізму, в державному їх різновиді ми зустрічаємо в ролі власників чиновництво, службовців, військових та інших представників розгалуженого державного апарату. Відмінністю феодалізму від рабовласництва і в приватних, і в державних формах прояву є те, що власністю на знаряддя праці в феодалізмі, незалежно від форм, наділений підлеглий клас, в той час коли в рабовласництві вони залишаються у власності панівного класу.

Капіталізм, незалежно від форм прояву, відрізняється від попередніх укладів непрямим економічним характером експлуатації, яка характерна і для приватного, i для державного його різновидів (незважаючи навіть на додаткові адміністративні заходи експлуатації в державному капіталізмі, які, в цілому, не впливають на загальну картину, а слугують своєрідним додатковим маркером його ідентифікації).

Відмінність приватної і державної форми капіталізму в цілому схожа на відповідну відмінність цих форм у рабовласництві. В приватному капіталізмі суб'єктами експлуатації та власниками предметів і засобів праці виступають приватні особи - представники панівного класу. Натомість в державному капіталізмі таким суб'єктом і власником виступає державний апарат (чиновництво, партійна номенклатура, адміністрація підприємств тощо). 
Табл. 2. Характеристики рабовласництва в приватному та державному різновидах

\begin{tabular}{|l|l|l|}
\hline Рабовласництво & приватна форма & державна форма \\
\hline \hline Характер експлуатації & $\begin{array}{l}\text { позаекономічнй } \\
\text { (прямий примус) }\end{array}$ & $\begin{array}{l}\text { позаекономічний } \\
\text { (прямий примус) }\end{array}$ \\
\hline Суб'єкт експлуатації & $\begin{array}{l}\text { приватні особи } \\
\text { (панівний клас) }\end{array}$ & $\begin{array}{l}\text { службові особи } \\
\text { (державний апарат) }\end{array}$ \\
\hline $\begin{array}{l}\text { Власність на предмети } \\
\text { праці }\end{array}$ & $\begin{array}{l}\text { приватна } \\
\text { (панівний клас) }\end{array}$ & $\begin{array}{l}\text { державна } \\
\text { (службові особи) }\end{array}$ \\
\hline $\begin{array}{l}\text { Власність на засоби } \\
\text { виробництва }\end{array}$ & $\begin{array}{l}\text { приватна } \\
\text { (панівний клас) }\end{array}$ & $\begin{array}{l}\text { державна } \\
\text { (службові особи) }\end{array}$ \\
\hline
\end{tabular}

Табл. 3. Характеристики феодалізму в приватному та державному різновидах

\begin{tabular}{|l|l|l|}
\hline Феодалізм & приватна форма & державна форма \\
\hline \hline Характер експлуатації & $\begin{array}{l}\text { позаекономічний } \\
\text { (прямий примус) }\end{array}$ & $\begin{array}{l}\text { позаекономічний } \\
\text { (прямий примус) }\end{array}$ \\
\hline Суб'єкт експлуатації & $\begin{array}{l}\text { приватні особи } \\
\text { (панівний клас) }\end{array}$ & $\begin{array}{l}\text { службові особи } \\
\text { (державний апарат) }\end{array}$ \\
\hline $\begin{array}{l}\text { Власність на предмети } \\
\text { праці }\end{array}$ & $\begin{array}{l}\text { приватна } \\
\text { (панівний клас) }\end{array}$ & $\begin{array}{l}\text { державна } \\
\text { (службові особи) }\end{array}$ \\
\hline $\begin{array}{l}\text { Власність на засоби } \\
\text { виробництва }\end{array}$ & $\begin{array}{l}\text { приватна } \\
\text { (підлеглий клас) }\end{array}$ & $\begin{array}{l}\text { приватна } \\
\text { (підлеглий клас) }\end{array}$ \\
\hline
\end{tabular}

Табл. 4. Характеристики капіталізму в приватному та державному різновидах

\begin{tabular}{|l|l|l|}
\hline Капіталізм & приватна форма & державна форма \\
\hline \hline Характер експлуатації & $\begin{array}{l}\text { непрямий економічний } \\
\text { примус }\end{array}$ & $\begin{array}{l}\text { непрямий економічний } \\
\text { примус }\end{array}$ \\
\hline Суб'єкт експлуатацї & $\begin{array}{l}\text { приватні особи } \\
\text { (панівний клас) }\end{array}$ & $\begin{array}{l}\text { службові особи } \\
\text { (державний апарат) }\end{array}$ \\
\hline $\begin{array}{l}\text { Власність на предмети } \\
\text { праці }\end{array}$ & $\begin{array}{l}\text { приватна } \\
\text { (панівний клас) }\end{array}$ & $\begin{array}{l}\text { державна } \\
\text { (службові особи) }\end{array}$ \\
\hline $\begin{array}{l}\text { Власність на засоби } \\
\text { виробництва }\end{array}$ & $\begin{array}{l}\text { приватна } \\
\text { (панівний клас) }\end{array}$ & $\begin{array}{l}\text { державна (службові } \\
\text { особи апарату) }\end{array}$ \\
\hline
\end{tabular}

Відтак, можна зауважити, що державний різновид існування формацій характерний для суспільств, в яких в силу різних причин існувала необхідність у сильній владі в якості доцентрового чинника (наприклад, природні умови Китаю, що потребували організації іригаційного землеробства). Тому носіями державної форми антагоністичних формацій часто виступають східні країни (так звані східні деспотії), пройняті національними, релігійними, соціальними конфліктами, які можна назвати багатонаціональними чи мультирелігійними тощо. 
Таким чином, розрізнення приватних та державних форм антагоністичних формацій дозволяє узгодити деякі суперечності, притаманні сучасній формаційній теоріі. Так, зокрема, уявлення про державне рабовласництво та феодалізм дозволяє окреслити в рамках цих звичних формацій АCB як окремий уклад, що не піддається класифікації. Державна форма існування феодалізму дозволяє «повернути» із «окремішнього» шляху Київську Русь та Російську імперію на дорогу загальнолюдського історичного процесу. Державний капіталізм дає змогу переосмислити сторінки так званої соціалістичної історії багатьох країн світу та врешті розгадати феномен сучасного Китаю. Разом з тим, можна обережно припустити існування певних прогностичних функцій формаційної теорії в такому її вигляді, зробивши спробу представити нове інформаційне суспільство в його приватному та державному різновиді.

\section{Література}

[1] Андерсон П. Переходы от античности к феодализму. - Москва: Территория будущего, 2007.

[2] Белл Д. Грядущее постиндустриальное общество. Опыт социального прогнозирования. - Москва: Academia, 2004.

[3] Валлерстайн И. Исторический капитализм. Капиталистическая цивилизация. - Москва: Товарищество научных изданий KMK, 2008 .

[4] Дарендорф Р. Современный социальный конфликт. Очерк политики свободы / Пер. с нем. - Москва: Российская политическая энциклопедия, 2002.

[5] Дементьева B.В. Труд Э.Ш. Вельскопф «Производственные отношения на Древнем Востоке и в греко-римской античности» как факт историографии: влияние предшественников // Проблемы истории, филологии, культуры. - Москва: РАН - Магнитогорск, 2004. - Вып. 13. - С. 18-27.

[6] Дискуссия об азиатском способе производства: по докладу М.С. Годеса. - Москва: Либроком, 2009.

[7] Захаров A.B. Еще раз о теории формаций // Общественные науки и современность. 1992. - № 2. - С. 46-55. 
[8] Иноземцев В.Л. Современное постиндустриальное общество: природа, противоречия, перспективы. - Москва : Логос, 2000.

[9] Клифб Т. Государственный капитализм в России. - Москва, 1991.

[10] Лейн Д. Глобальный капитализм и трансформация государственного социализма / Пер. с англ. О.А. Оберемко / Социологический журнал. - 2015. - № 1. - С. 51-72.

[11] Пайпс Р. Россия при старом режиме. - Москва: Независимая газета, 1993.

[12] Плеханов Г.В. Избранные философские произведения. В 5 т. Т. 1. - Москва : Государственное издательство политической литературы, 1956.

[13] Попов Г.Г. Дискуссии о характере социально-экономического развития средневековой Руси в отечественной и зарубежной науке ХХ века // Историко-экономические исследования. - Т. 9. - 2009. - № 2. - С. 33-47.

[14] Семенов Ю.И. Марксова теория обшественно-экономических формаций и современность // Философия и общество. - 1998. - № 3. - C. 190-223.

[15] Хардm M., Негри А. Империя / Пер. с англ., под ред. Г.В. Каменской, М.С. Фетисова. - Москва : Праксис, 2004.

[16] Callinicos A. The revenge of history: Marxism and the East European revolutions. - Cambridge: Polity Press 1991. 1

[17] Castells M. End of Millennium, Volume III: The Information Age: Economy, Society and Culture. - Chichester : Wiley-Blackwell, 2010.

[18] Habermas J. The Structural Transformation of the Public Sphere. An Inquiry into a Category of Bourgeois Society. - Cambridge, Massachusets: The MIT Press, 1991.

[19] Resnick S.A., Wolf R.D. Class theory and history: capitalism and communism in the USSR. - New York ; London : Routledge, 2002.

[20] Rockmore T. Marx's Dream: From Capitalism to Communism. - Chicago : University of Chicago Press, 2018. 
[21] Wittfogel K.A. Oriental Despotism: A Comparative Study of Total Power. - New Haven : Yale University Press, 1957.

\section{References}

[1] Anderson P. Perekhody ot antichnosti k feodalizmu. - Moskva : Territoriya budushchego, 2007.

[2] Bell D. Gryadushchee postindustrialnoe obshchestvo. Opyt socialnogo prognozirovaniya. - Moskva: Academia, 2004.

[3] Vallerstajn I. Istoricheskij kapitalizm. Kapitalisticheskaya civilizaciya. - Moskva : Tovarishchestvo nauchnyh izdanij KMK, 2008.

[4] Darendorf R. Sovremennyj socialnyj konflikt. Ocherk politiki svobody. - Moskva : Rossijskaya politicheskaya enciklopediya, 2002.

[5] Dementieva V.V. Trud E.SH. Velskopf «Proizvodstvennye otnosheniya na Drevnem Vostoke i v greko-rimskoj antichnosti» kak fakt istoriografii: vliyanie predshestvennikov // Problemy istorii, filologii, kultury. - Moskva: RAN - Magnitogorsk, 2004. - Vyp. 13. - S. 18-27.

[6] Diskussiya ob aziatskom sposobe proizvodstva: po dokladu M.S. Godesa. - Moskva : Librokom, 2009.

[7] Zaharov A.V. Eshche raz o teorii formacij // Obshchestvennye nauki i sovremennost. 1992. - № 2. - S. 46-55.

[8] Inozemcev V.L. Sovremennoe postindustrialnoe obshchestvo: priroda, protivorechiya, perspektivy. - Moskva: Logos, 2000.

[9] Kliff T. Gosudarstvennyj kapitalizm v Rossii. - Moskva, 1991.

[10] Lejn D. Globalnyj kapitalizm i transformaciya gosudarstvennogo socializma // Sociologicheskij zhurnal. - 2015. - № 1. - S. 51-72.

[11] Pajps R. Rossiya pri starom rezhime. - Moskva: Nezavisimaya gazeta, 1993.

[12] Plekhanov G.V. Izbrannye filosofskie proizvedeniya. V 5 t. T.1. Moskva: Gosudarstvennoe izdatelstvo politicheskoj literatury, 1956. 
[13] Popov G.G. Diskussii o haraktere socialno-ekonomicheskogo razvitiya srednevekovoj Rusi v otechestvennoj i zarubezhnoj nauke XX veka // Istoriko-ekonomicheskie issledovaniya. - T. 9. - 2009. - № 2. - S. 33-47.

[14] Semenov YU.I. Marksova teoriya obshestvenno-ekonomicheskih formacij i sovremennost // Filosofiya i obshchestvo. - 1998. - № 3. - S. 190-223.

[15] Hardt M., Negri A. Imperiya. - Moskva: Praksis, 2004.

[16] Callinicos A. The revenge of history: Marxism and the East European revolutions. - Cambridge: Polity Press 1991.

[17] Castells M. End of Millennium, Volume III: The Information Age: Economy, Society and Culture. - Chichester : Wiley-Blackwell, 2010.

[18] Habermas J. The Structural Transformation of the Public Sphere. An Inquiry into a Category of Bourgeois Society. - Cambridge, Massachusets: The MIT Press, 1991.

[19] Resnick S.A., Wolf R.D. Class theory and history: capitalism and communism in the USSR. - New York ; London : Routledge, 2002.

[20] Rockmore T. Marx's Dream: From Capitalism to Communism. - Chicago : University of Chicago Press, 2018.

[21] Wittfogel K.A. Oriental Despotism: A Comparative Study of Total Power. - New Haven: Yale University Press, 1957.

Надійшла до редакиї̈ 17 вересня 2020 р. 
Брюховецький Микола Миколайович

Кафедра філософії

Криворізький державний педагогічний університет

просп. Гагаріна, 54

м. Кривий Ріг

50086

\section{Briukhovetskyi Mykola}

Department of Philosophy

Kryvyi Rih State Pedagogical University

Gagarina ave., 54

Kryvyi Rih

50086

iD https://orcid.org/0000-0001-7103-5620

@briukhovetskyi@gmail.com

doi) 10.31812 /apd.v0i21.4372 